\title{
A 2011 update for the single-layer desulphurised tailings cover completed in 1999 at Detour Gold
}

\author{
A.E. Cash Department of Civil and Environmental Engineering, University of Alberta, Canada \\ P. Urrutia Norman B. Keevil Institute of Mining, University of British Columbia, Canada \\ G.W. Wilson Department of Civil and Environmental Engineering, University of Alberta, Canada \\ J. Robertson Detour Gold Corporation, Canada
}

M.H. Turgeon Detour Gold Corporation, Canada

\begin{abstract}
A desulphurised tailings cover was installed to reduce oxygen diffusion into underlying sulphidic tailings at the Detour Lake Mine in Ontario, Canada between 1998 and 1999. This paper reviews the outcomes of the original characterisation of the desulphurised cover in 2000 and evaluates performance of the cover following an investigation completed 11 years after installation. A holistic view of the tailings system is discussed including water quality testing, fish populations within the tailings management area, and geochemical analyses of the desulphurised cover.
\end{abstract}

An initial site investigation and numerical modelling were completed by Sjoberg-Dobchuk et al. (2003) to instrument the cover and monitor the water content profile, as well as to collect tailings samples for geotechnical and geochemical characterisation. Numerical simulations concluded that the tailings cover would not maintain greater than $85 \%$ saturation within the region of the beach. However, oxygen flux rates through the desulphurised cover to the underlying tailings were still found to be reduced to $2 \mathrm{~mole} / \mathrm{m}^{2} / \mathrm{yr}$ or less due the consumption oxygen by the residual sulphide content within the cover profile. This study indicated the cover was effective in preventing ARD.

A follow-up study was conducted in August 2011 to assess the performance of the cover system prior to flooding by new tailings. A site investigation was conducted at the original instrumentation locations to collect samples for geochemical analyses. The laboratory results and visual observations indicated the cover is performing well, without maintaining $>85 \%$ saturation. Water quality sampling of the tailings pond water generally met or exceeded the Ontario Provincial Water Quality Objectives and the tailings pond supported a substantial population of four fish species. The study provided further confirmation that the profile of the desulphurised tailings cover profile has not become acidic and the cover performance has met the initial design expectations.

\section{Introduction}

The management of acid rock drainage (ARD) in mine waste is a principal environmental issue facing the mining industry globally. ARD is generated in tailings and waste rock by the oxidation of sulphide bearing minerals with atmospheric water and oxygen to produce acidic drainage (MEND, 2001). ARD can be mitigated primarily through the implementation of measures to prevent or control the rate of sulphide oxidation, by limiting the availability of water and oxygen. A typical mitigation strategy involves the installation of an engineered cover system (INAP, 2009b). Rehabilitation of tailings utilising an oxygen barrier is a method for controlling and mitigating ARD, and requires that a material can consume oxygen or prevent oxygen flow (Bussière et al., 2004). Environmental desulphurisation of mine tailings can be used as a cover material and acts as a combined oxygen barrier and method for oxygen consumption. Environmental desulphurisation involves the removal of sulphide minerals from mine tailings to reduce the acid potential (AP) of the waste products with the subsequent result of an increase in the net neutralising 
potential (NNP) (Bussière, 2007; INAP, 2009b). Desulphurisation is completed through mineral separation of sulphides, which result in two fractions for management: a non-acid generating desulphurised tailings stream and a sulphide concentrate (Bussière, 2007; Bois et al., 2005). In addition to improving the chemical stability of the tailings, the tailings can be used as a cover material due to the high NNP (Bussière, 2007). Covers constructed with desulphurised tailings are non-acid generating and do not require additional measures such as a water cover (Bois et al., 2005). Re-vegetation of these tailings covers is also possible to prevent erosion and to promote evapotranspiration.

Both laboratory and field investigations have been conducted to understand and quantify the economic and environmental benefits to partial desulphurisation. A column study (Bussière et al., 2004) of a cover with capillary barrier effects (CCBE) was constructed with desulphurised tailings as the moisture retaining layer designed to prevent oxygen flow. The desulphurised tailings retained high saturation, and oxygen consumption within the moisture retaining layer reduced the sulphate concentration in the column leachate. This improved cover performance (Bussière et al., 2004). A field scale experiment conducted in northern Québec (MEND, 1999) utilised completely desulphurised tailings as a moisture retaining layer in a composite cover. Environmental desulphurisation can be achieved through froth flotation as part of the milling process, where a ratio of two for the neutralising potential to acid potential is considered acceptable to prevent ARD (Benzaazoua et al., 2000). Acid base accounting (ABA) analyses, to characterise the amount of sulphides and potential acid generation as well as the natural neutralising capacity, must be employed to determine the level of sulphide reduction required (Benzaazoua et al., 2000).

A partially desulphurised cover was installed at the Detour Lake Project in Ontario, Canada between 1998 and 1999 just prior to the termination of operations. The single layer cover was installed over existing sulphidic tailings by end-of-pipe slurry discharge, and was used as the method of closure in combination with a partial water cover. The objective of the cover design concept was to maintain $>85 \%$ saturation to limit oxygen diffusion and to consume oxygen utilising the residual sulphur content, without contributing to ARD generation (Sjoberg-Dobchuk et al., 2003). The oxygen diffusion mechanism and theory for diffusion into a desulphurised cover is presented in detail in Sjoberg-Dobchuk et al. (2003). After installation, the cover was instrumented and characterised to assess performance. This paper discusses the initial site investigation in July 2000 and a follow-up investigation in August 2011 to evaluate the cover performance after 11 years. Pond water quality and fish populations present in the pond will also be discussed.

\section{Site history}

Placer Dome Inc. operated the Detour Lake Mine from 1983 to 1999, which is located approximately $300 \mathrm{~km}$ northeast of Timmins, Ontario. The site is located in a moist continental mid-latitude climate and the temperature ranges between $37^{\circ} \mathrm{C}$ and $-47^{\circ} \mathrm{C}$ (Sjoberg-Dobchuk et al., 2003). Fifteen million tonnes of sulphidic gold tailings were deposited by end-of-pipe slurry discharge in a single 244 ha impoundment at closure (Sjoberg-Dobchuk et al., 2003). The remediation strategy for the tailings involved the installation of a combined desulphurised and water cover (Sjoberg-Dobchuk et al., 2003). Purchase of the mine in 2006 by Detour Gold Corporation (DGC), and subsequent expansion of the existing tailings impoundment presented a unique opportunity to sample and assess the state of the desulphurised cover, prior to flooding with new tailings. The existing sulphidic tailings mineralogy is dominated by pyrite, with a sulphide content ranging from $1-2.5 \%$ by mass (Sjoberg-Dobchuk et al., 2003). The desulphurised tailings cover consisted of a single layer ranging in thickness from greater than $1 \mathrm{~m}$ near the discharge point to $0.5 \mathrm{~m}$ near the pond (SjobergDobchuk et al., 2003). The sulphide content was reduced to less than $1 \%$ through a secondary flotation process in a desulphurisation circuit that was installed in the original mill. Subsequent deposition via endof-pipe slurry discharge resulted in a segregated heterogeneous grain size profile (Sjoberg-Dobchuk et al., 2003).

The tailings pond forms the headwaters of the drainage area due to the locally flat terrain. The Detour Lake area receives approximately $850-920 \mathrm{~mm}$ of precipitation, which typically exceeds the evaporation level by approximately 100-500 mm (AMEC Earth \& Environmental, 2010; Sjoberg-Dobchuk et al., 2003). The pond level was maintained through use of an outflow weir to create a stable shoreline throughout the operation 
of the tailings pond. The pond discharge volume is approximately $900,000 \mathrm{~m}^{3}$ annually. A natural open weir with a gravel channel controlled the annual pond fluctuations, where the drop in elevation is approximately $25 \mathrm{~m}$ to a downstream lake. Flows typically occurred in spring and fall, with little to no flow for the dry summer period. Major flooding and drying cycles are believed to be minimal, as well as ice scouring of the shoreline areas as a result of the weir. The shoreline surficial materials were not examined during 2011 due to access problems while the pond was being dewatered for preparation for future use.

\section{$3 \quad$ Methodology}

A site investigation was initially conducted in July 2000, with a follow-up investigation in August 2011 to evaluate the geotechnical and geochemical characteristics of the cover. The water cover on the tailings pond during operations accounted for approximately $55 \%$ of the total area. The pond residence time is unknown as the outflow weir conducts flows primarily in the spring and fall, and influences of large storm events and freezing in the winter months can vary pond outflow. The area surrounding the pond collection is well covered by vegetation, ranging from full established tree and bushes to aquatic reeds which are ideal for fish reproduction. The lake was populated by beavers and used by nesting birds including Canada Geese. The discharge channel was a cobble and gravel stream bed which was generally devoid of vegetation due to limited organic substrate and dry conditions during the summer when the flows naturally stopped. The initial investigation involved the installation of nine neutron probe access tubes and piezometers located along three profiles, A, B, and C within the desulphurised cover (Figure 1).

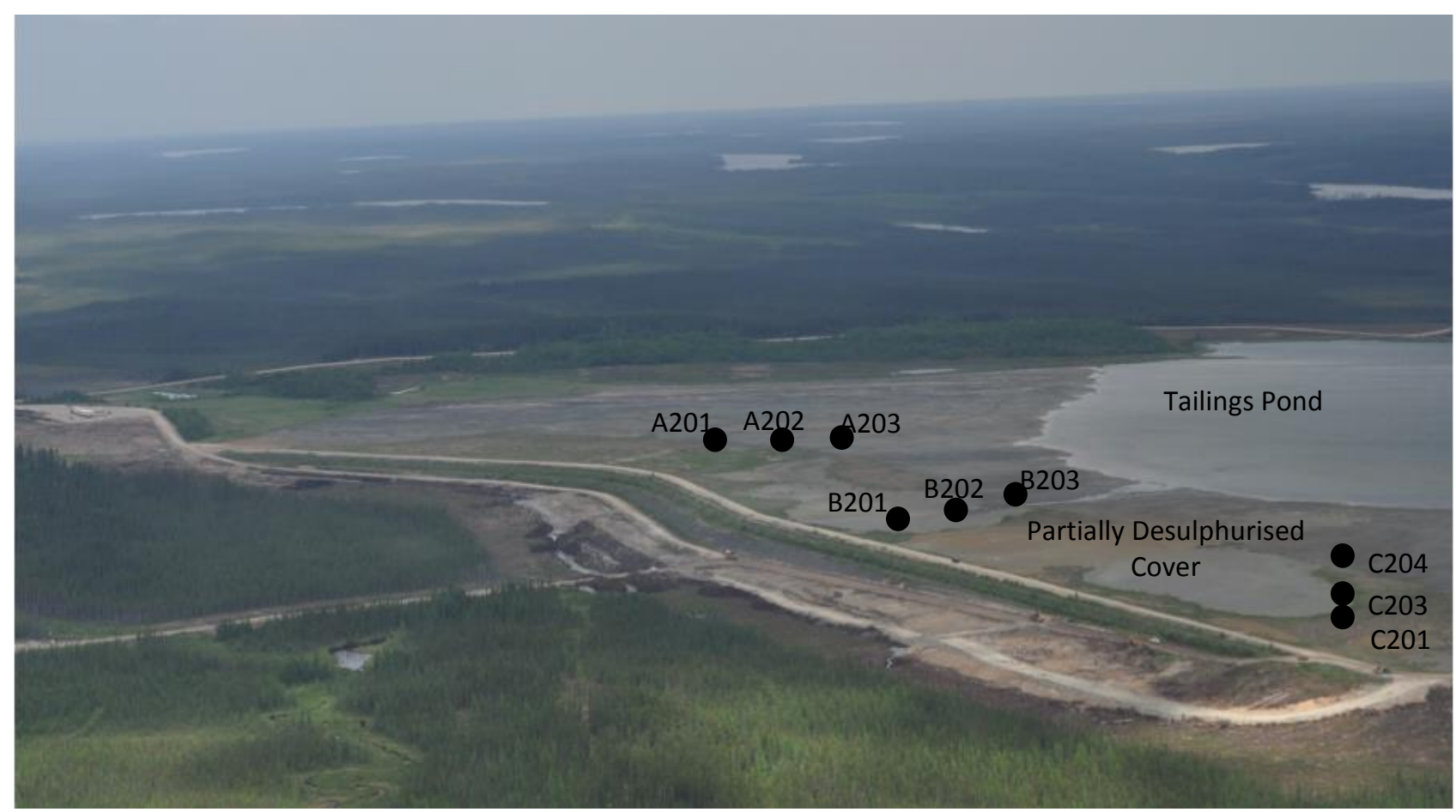

\section{Figure 1 Photo of Detour Lake mine tailings impoundment in August 2011 indicating the approximate location of the desulphurised cover and instrumentation profiles}

Instrument location C202 did not extend to a sufficient depth, and was replaced by location C204 during the field installation. The initial site investigation delineated the water content profiles and water level from July 2000 to July 2001, and acquired meteorological data through an installed weather station adjacent to B201 (Sjoberg-Dobchuk et al., 2003). A total of 41 samples were collected for geotechnical characterisation. Twenty-two samples were used to assess grain size, and six representative samples were used to determine the saturated hydraulic conductivity and the soil-water characteristic curves (SWCC) (Sjoberg-Dobchuk et al., 2003). Geochemical analyses were performed on 38 samples, and included static ABA including net neutralising potential (NNP), net acid generation potential (NAG) $\mathrm{pH}$, and paste $\mathrm{pH}$. 
Mineralogy was determined by X-ray diffraction and petrography (Sjoberg-Dobchuk et al., 2003). These data were utilised in a predictive model using SoilCover to couple the soil-atmospheric interactions. A diffusion reaction model in MatLab was used to analyse oxygen consumption (Sjoberg-Dobchuk et al., 2003).

A similar site investigation was conducted in August 2011 to characterise the tailings cover after 11 years. Eight of the original nine instrumentation stations were located, with one piezometer in profile $C$ not found. A hand auger was utilised to collect a total of 39 samples to a depth of $1.5 \mathrm{~m}$. The samples were used to determine the water content profile, and in situ measurements of soil suction were completed to a depth of $0.5 \mathrm{~m}$. Laboratory characterisation of the samples included static ABA tests including NNP, NAG $\mathrm{pH}$, paste $\mathrm{pH}$, and a metals analysis by aqua regia digestion followed by inductively coupled plasma mass spectrometry (ICP-MS). Post-closure water quality data was also collected at the tailings spillway.

\section{$4 \quad$ Results and discussion}

\subsection{Initial field study (2000)}

The soil-water characteristic curves (SWCC) for the desulphurised and sulphidic tailings are presented in Figure 2, where solid symbols represent the desulphurised tailings samples, and hollow symbols are the sulphidic tailings samples. The initial laboratory investigation indicated that the grain size of the desulphurised tailings were generally coarser, which is reflected in the lower air entry value (AEV) of the cover material. The AEV of the desulphurised tailings samples were 6 to $20 \mathrm{kPa}$ (Sjoberg-Dobchuk et al., 2003). On average, the saturated hydraulic conductivity of the tailings ranged from $2 \times 10^{-6}$ to $1 \times 10^{-7} \mathrm{~m} / \mathrm{s}$, and the specific gravity of the desulphurised tailings was 2.87, and 2.91 for the sulphidic tailings (SjobergDobchuk et al., 2003).

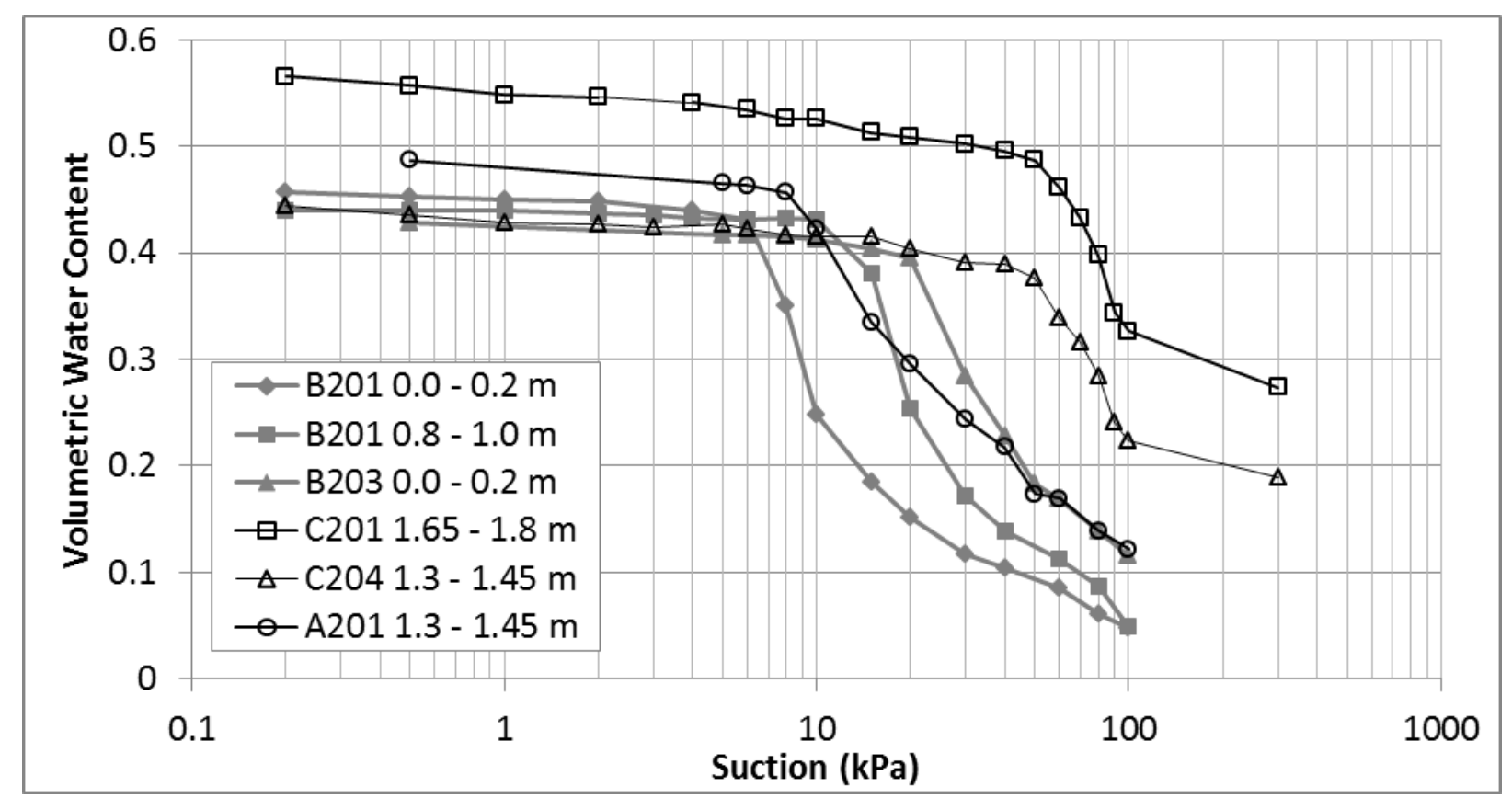

Figure 2 Soil-water characteristic curve of six samples of varying grain size from July 2000 site investigation (after Sjoberg-Dobchuk et al., 2003)

Static ABA data indicated that the reduction of the sulphide content to $<1 \%$ was sufficient to consume oxygen entry by diffusion as well as provide sufficient residual neutralisation capacity such that the material would not generate ARD (Sjoberg-Dobchuk et al., 2003). ABA analyses identified an increase in sulphide content with depth, resulting in an 'uncertain' zone between the desulphurised zone and the underlying sulphidic tailings, which may or may not have the potential to produce acid. Water content profiles determined through the cover were assessed in parallel with the geochemical analyses, indicating that 
some of the 'uncertain' zone and sulphidic tailings may not maintain greater than $85 \%$ saturation (SjobergDobchuk et al., 2003). Four of the nine boreholes did not maintain $>85 \%$ saturation, potentially allowing oxygen diffusion to the reactive layer, and consequently, potential for oxidation in these zones exists. The results of geochemical analyses at each instrumentation location can be found in Sjoberg-Dobchuk et al. (2003).

\subsubsection{Numerical modelling}

Numerical modelling was conducted using SoilCover to assess the potential for oxygen diffusion into the cover. Material properties, depth to the water table, success of vegetation, and grain size were varied to generate four profiles that depicted the range of conditions determined during the initial site investigation. Weather data collected from the onsite weather station represented a 1-in-50 dry year. The numerical analyses supported the field investigation data indicating that at four sampling locations, the cover would not achieve greater than $85 \%$ saturation and oxygen entry into the pore space would occur (SjobergDobchuk et al., 2003).

Oxygen diffusion and consumption modelling was conducted using numerical methods specifically related to the site conditions at Detour Lake Mine. Numerical modelling evaluated differing grain sizes in the cover and underlying tailings and indicated that a fine desulphurised tailings cover would reduce the oxygen influx to $2 \mathrm{~mole} / \mathrm{m}^{2} / \mathrm{yr}$, equivalent to the oxygen diffusion rate through a water cover $0.5-1 \mathrm{~m}$ in depth. A cover profile with a coarse desulphurised layer over a fine sulphidic layer may not provide sufficient oxygen consumption if the water table is at a depth of $4 \mathrm{~m}$ (Sjoberg-Dobchuk et al., 2003). A detailed description of the numerical modelling parameters and procedure is presented in Sjoberg-Dobchuk et al. (2003), as well as a description of the parametric analyses used to evaluate oxygen flux. Figures 3 and 4 present per cent saturation and oxygen concentrations through a coarse tailings cover layer over a fine grained sulphidic tailings layer. The profiles are constructed using mean and wet weather data, where the saturation profiles illustrate the wetting and drying nature of varied grain size tailings, and the corresponding oxygen diffusion response (Sjoberg Dobchuk et al., 2003).

The saturation profiles for a mean weather year (Figure 3, left) and wet weather year (Figure 3, right) show little variation in simulations, and in both cases the surface maintained approximately $5 \%$ saturation and the coarse layer ranged from 30 to $60 \%$ saturation. The oxygen concentration profiles illustrate the response to wetting fronts, which decreases the depth of oxygen penetration. The reaction rate constant, $\mathrm{k}_{\mathrm{r}}$, differs in the coarse and fine tailings layers, as finer tailings have increased surface area and therefore a greater rate of oxidation (Sjoberg-Dobchuk et al., 2003).
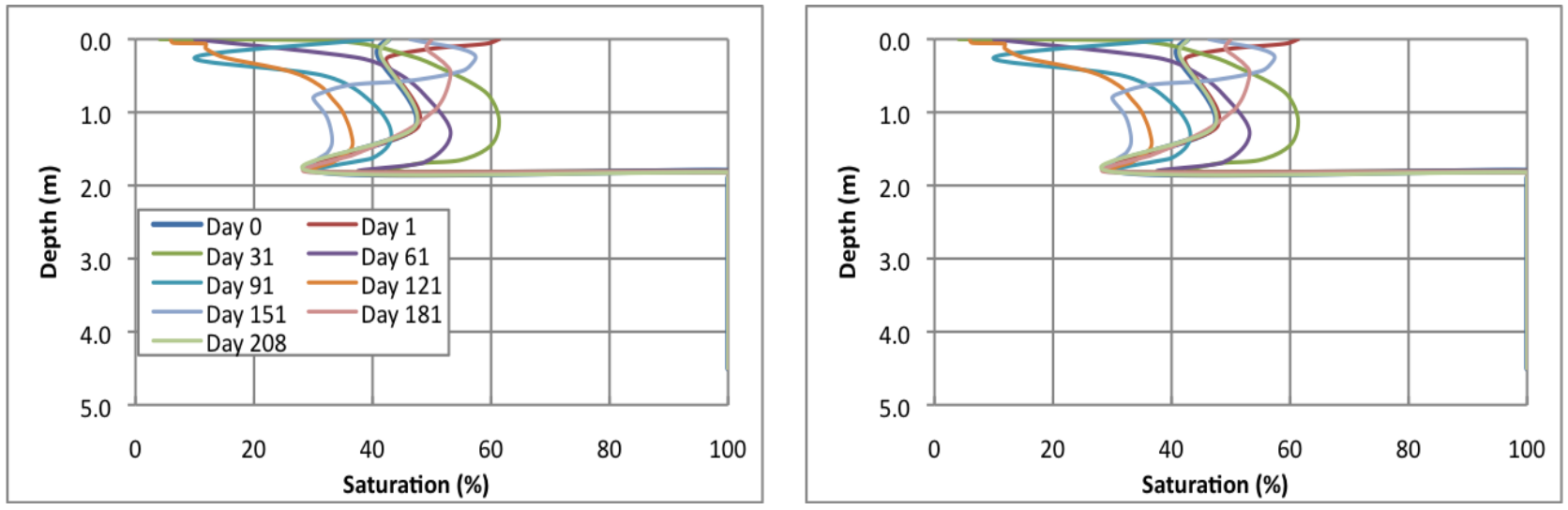

Figure 3 Percent saturation profile from SoilCover modelling for $1.8 \mathrm{~m}$ coarse tailings layer over fine tailings and $4 \mathrm{~m}$ depth to water table for a) Mean weather data (left); b) Wet weather data (right) (after Sjoberg-Dobchuk et al., 2003) 

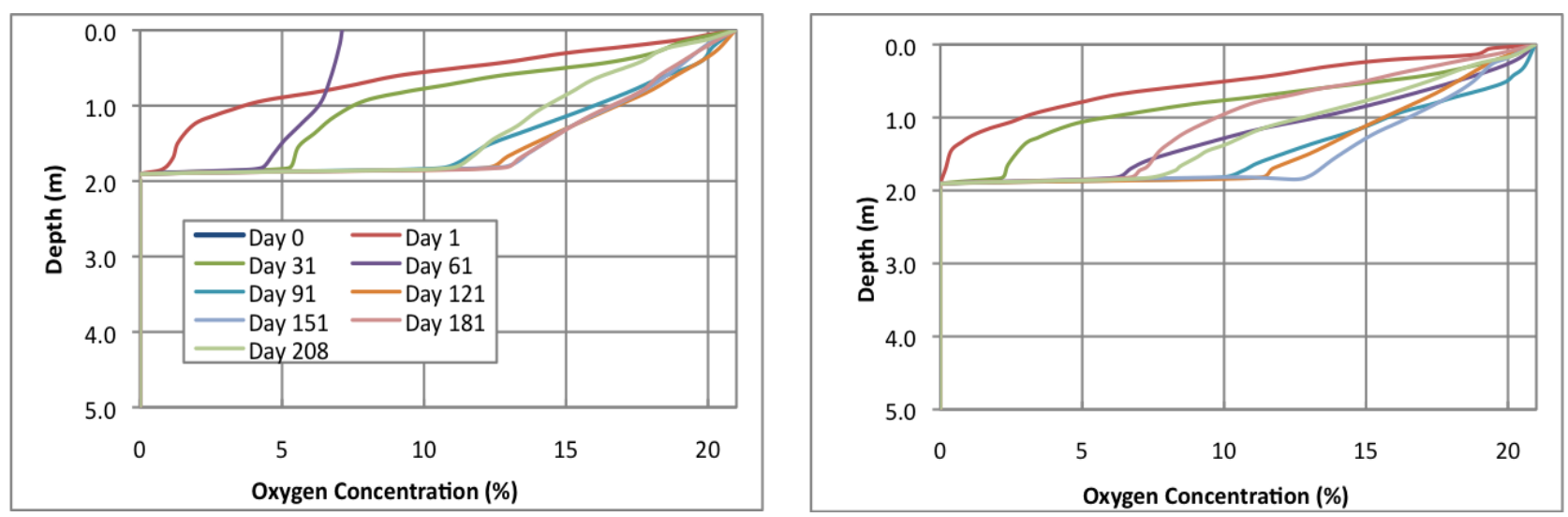

Figure 4 Oxygen concentration profiles for a $1.8 \mathrm{~m}$ thick layer of coarse tailings over fine tailings and $\mathbf{4} \mathrm{m}$ depth to water table. Reaction rate constants (kr) for coarse tailings: $k_{r}=3.42 / y r$; fine tailings: $k_{r}=191 / y r$; a) Mean weather data (left); b) Wet weather data (right) (after Sjoberg-Dobchuk et al., 2003)

The initial study concluded that in both field and numerical analyses, the cover will not maintain $85 \%$ saturation in coarser areas of the tailings, and that some influx of oxygen may occur. While Figures 3 and 4 show the saturation profiles in the coarse tailings to generally vary between 30 and $60 \%$, the oxygen concentration can be seen to decrease to zero at the base of the cover. In summary, the average oxygen flux through the cover was reduced to $2 \mathrm{~mole} / \mathrm{m}^{2} / \mathrm{yr}$ or less (Sjoberg-Dobchuk et al., 2003).

\subsection{Results of follow-up study (2011)}

The field investigation conducted in 2011 confirmed the heterogeneous nature of the desulphurised cover. The tailings surface was partially vegetated and occurred naturally as no re-vegetation program was completed on the partially desulphurised cap (Figure 5).

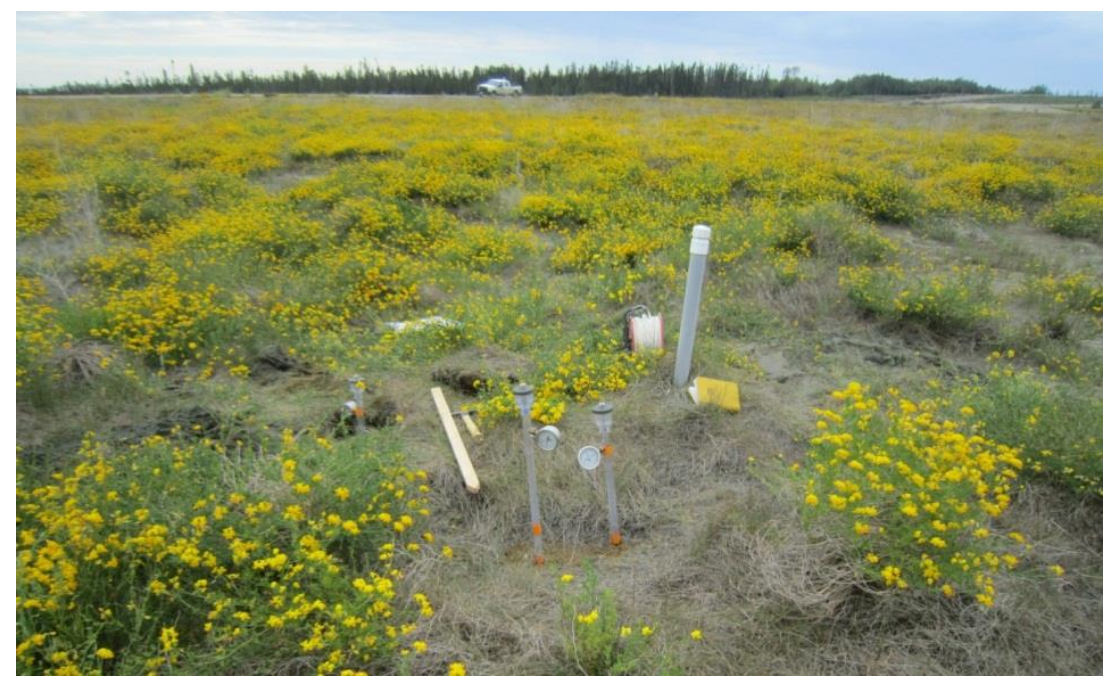

Figure 5 Piezometer at instrument location A202 in August 2011

Some areas of the cover do not have vegetation, however the majority of these non-vegetated areas surface were unoxidised tailings. There were small areas of tailings with evidence of oxidation that had a lateral extent less than 1-2 $\mathrm{m}^{2}$; however, no extensive areas of oxidation were observed. Furthermore, no oxidation front was evident with depth in the profile during sample collection. A typical sampling site of the cover in 2011 is illustrated in Figure 5, showing the existing piezometer A202 at the sampling location, and tensiometers installed to determine the soil suction profile. The photo illustrates grasses and other plants on the cover present in August during the dry season, where the grass is dry due to lack of precipitation during the summer months. 
The tailings impoundment was being de-watered at the time of the 2011 site investigation. As a result, water levels in three of the eight piezometer instrumentation locations were below the bottom of the well screen. The matric suction profile within the tailings ranged between 5 and $30 \mathrm{kPa}$, which is in the range of the air entry values of 6 to $20 \mathrm{kPa}$ determined by Sjoberg-Dobchuk et al. (2003). In coarser areas with lower $A E V s$, oxygen diffusion into the cover would be expected.

The results of the 2011 site investigation were compared with the initial characterisation study. Figure 6 presents the water content profiles for the tailings in 2002 and 2011. In July 2002, the highly variable nature of the water contents with depth are attributed to differences in particle sizes inherent in slurry discharge, as the residual moisture content in finer layers is higher due to a higher AEV. This variability was not as prominent in 2011, as a larger sampling interval was used, and physical samples were used rather than via neutron probe. Similar to the results in 2002 , $>85 \%$ saturation was not maintained in the cover profile in all locations in 2011. In general, the water content decreased in locations furthest from the pond with the top $0.5 \mathrm{~m}$ consistently drier than the remainder of the profile. The water contents in profile $A$ and profile $C$ appear to have decreased between the initial and follow-up field investigations; however, these two profiles are furthest from the pond-tailings cover interface, and this decrease may be the result of dewatering or due to drying in the summer months. In summary, these findings confirm the results obtained during the initial site investigation and predictive modelling program.
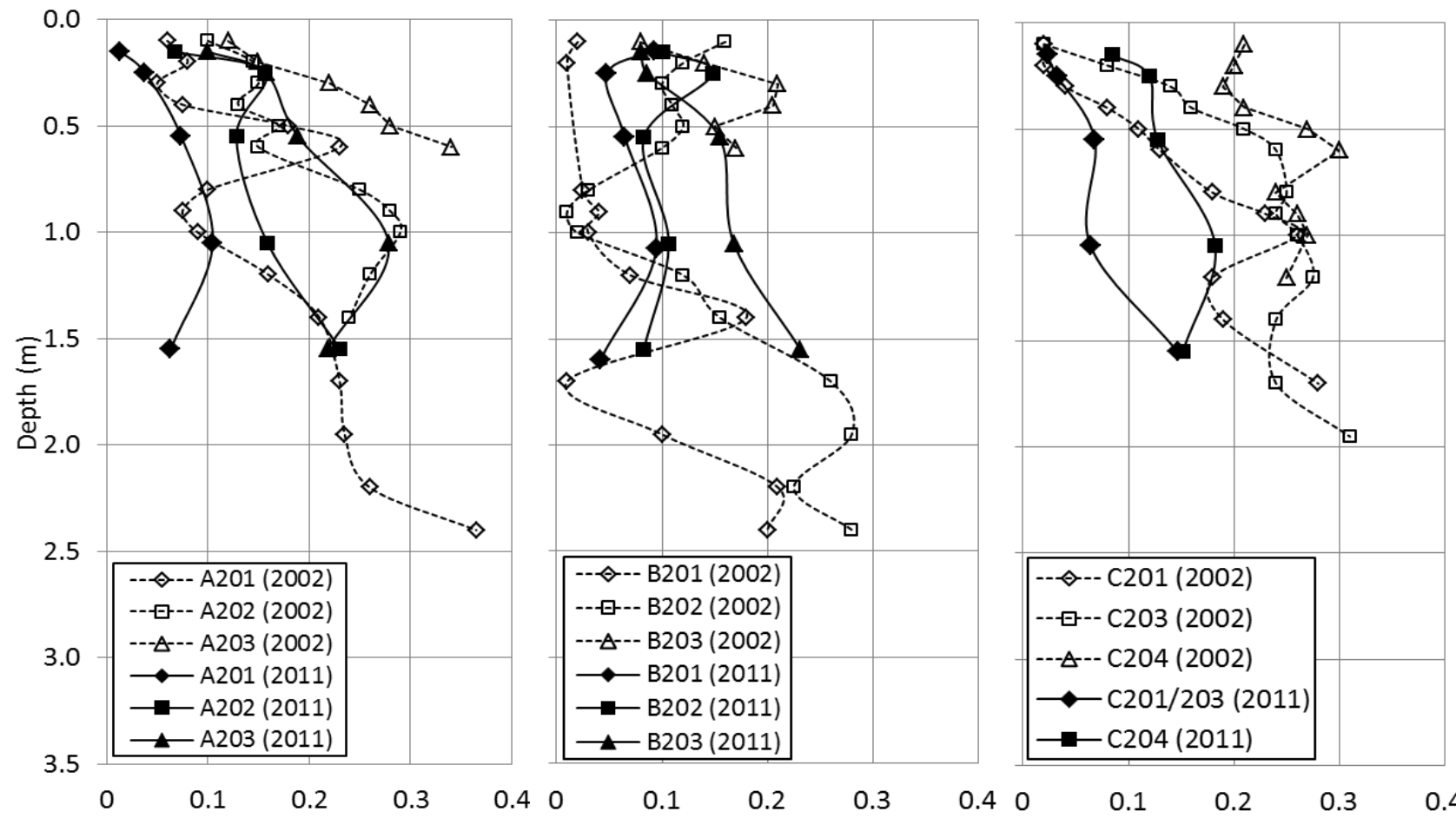

\section{Gravimetric Water Content}

\section{Figure 6 Water content profiles with depth from surface measured in July 2002 (neutron probe) and August 2011 (physical sample)}

\subsubsection{Laboratory results}

The geochemical analyses of the 38 samples obtained in 2011 are summarised in Table 1 . These data illustrate that there has been very limited reactivity in the layers sampled as the $\mathrm{pH}$ values are neutral and most of the samples had NP/AP ratios greater than 1.5, which has been adopted as an operating threshold criteria by DGC (J. Robertson, 14 May 2012, pers. comm.). These results are consistent with the total metals data obtained for the tailings pond water quality, which will be discussed in the following section. 
Table 1 Summary of geochemical analyses performed on 2011 samples $(n=38)$

\begin{tabular}{|c|c|c|c|c|c|c|c|c|c|}
\hline & $\begin{array}{c}\text { Paste } \\
\text { pH } \\
\text { Std. } \\
\text { Units }\end{array}$ & $\begin{array}{c}\text { Total } \\
\text { Sulphur } \\
\text { \% S }\end{array}$ & $\begin{array}{c}\text { Sulphate } \\
\text { \% S }\end{array}$ & $\begin{array}{c}\text { Sulphide } \\
\text { \% S }\end{array}$ & $\begin{array}{c}\text { Insoluble } \\
\text { Sulphur } \\
\text { \% S }\end{array}$ & $\begin{array}{c}\mathrm{AP} \\
\mathrm{kg} \\
\mathrm{CaCO}^{3} / \mathrm{t}\end{array}$ & $\begin{array}{c}\text { Modifie } \\
\text { d NP } \\
\text { kg } \\
\mathrm{CaCO}^{3} / \mathrm{t}\end{array}$ & $\begin{array}{c}\text { Net NP } \\
\text { kg } \\
\mathrm{CaCO}^{3} / \mathrm{t}\end{array}$ & $\begin{array}{c}\text { NP/A } \\
\mathbf{P} \\
\text { Ratio }\end{array}$ \\
\hline Average & 7.31 & 0.78 & 0.16 & 0.15 & 0.47 & 4.68 & 17.17 & 12.49 & 5.18 \\
\hline Minimum & 4.18 & 0.22 & 0.03 & 0.04 & 0.07 & 1.25 & 2.2 & -0.89 & 0.95 \\
\hline Maximum & 7.92 & 2.4 & 0.44 & 0.63 & 1.53 & 19.69 & 35.4 & 28.81 & 14.17 \\
\hline $\begin{array}{l}\text { Number of } \\
\text { samples } \\
\text { below } 1.5\end{array}$ & - & - & - & - & - & - & - & - & 2 \\
\hline
\end{tabular}

Paste $\mathrm{pH}$ testing was completed on 38 samples from the initial site investigation and 38 samples in the follow up study in 2011. The test was used as a screening tool to indicate the presence of readily available neutralising potential (NP) and stored acidity from surface oxidation. One sample from the 2011 study had a $\mathrm{pH}$ of less than five, and in 2000, no samples had a $\mathrm{pH}$ less than five. Figure 7 presents the paste $\mathrm{pH}$ results from the 2000 and 2011 field investigation. The trends of paste $\mathrm{pH}$ with depth do not indicate significant stored acidity with the vast majority of the paste $\mathrm{pH}$ values in the neutral range between $\mathrm{pH} 6$ and $\mathrm{pH} 8$.

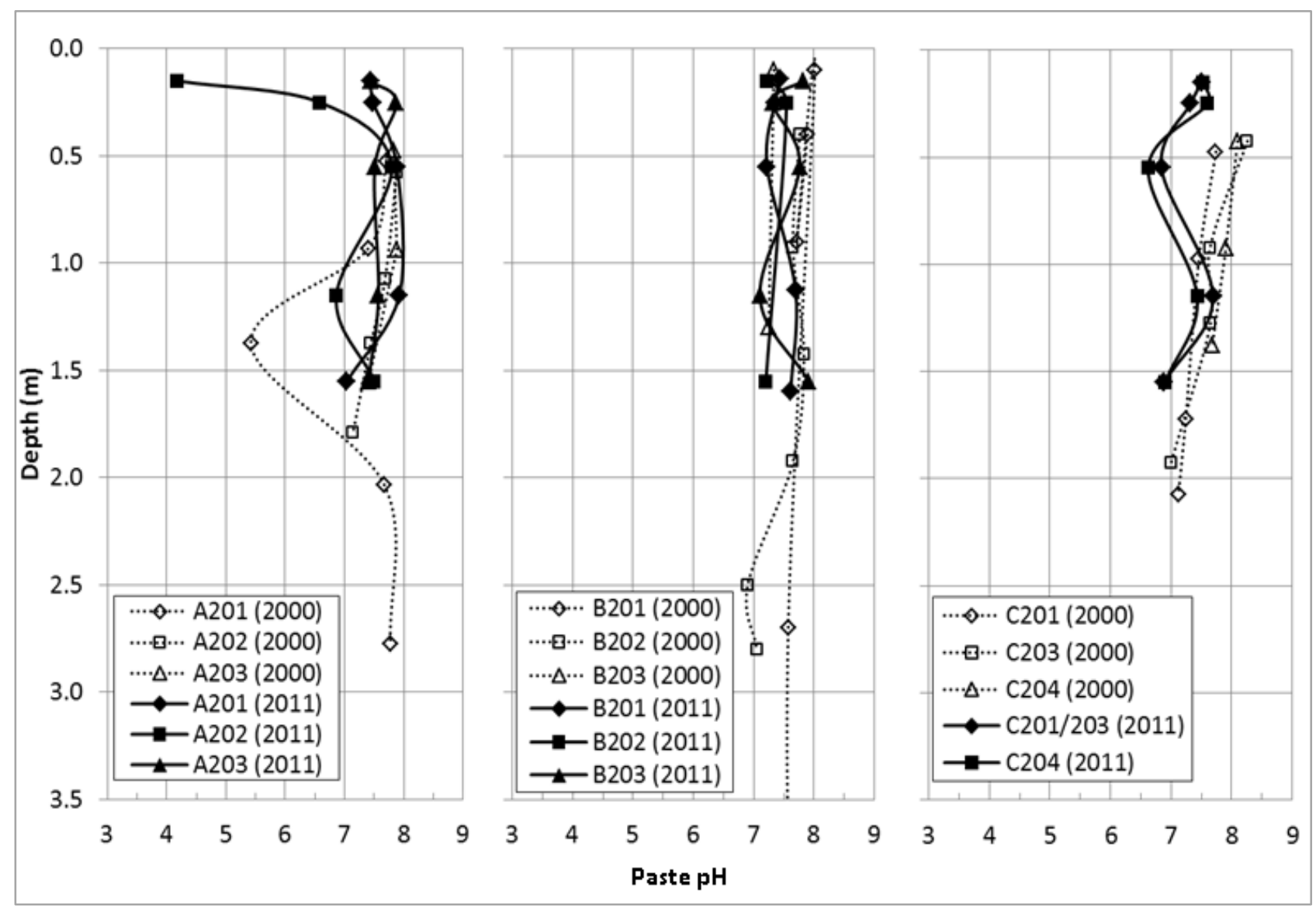

Figure 7 Paste pH profiles with depth from surface measured in 2000 and 2011 
Static geochemical tests were used to assess the potential for acid generation. Figure 8 presents the NNP and NAG pH for samples collected in both the initial and final characterisation study. NNP describes the difference between the neutralising potential and acid potential, and indicates the ability of the material to neutralise all acid in the system. Positive values indicate that the material has sufficient neutralising potential to neutralise all generated acid. NAG pH is used in combination with ABA data to provide a value that indicates the likelihood of acid generation. A NAG pH of less than 4.5 indicates that the sample is net acid generating (INAP, 2009a), and tailings with NNP less than -15 are also acid producing.

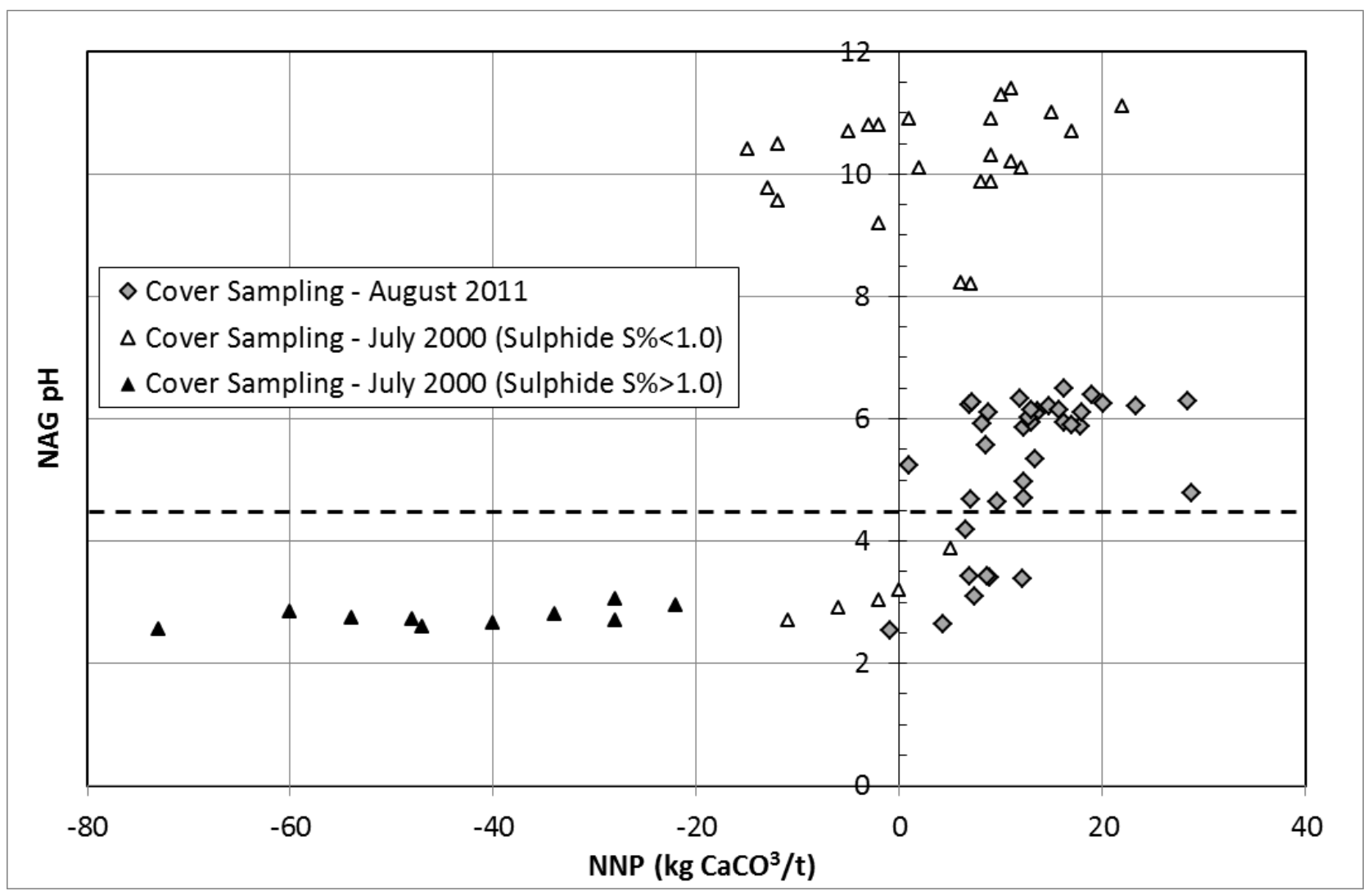

\section{Figure 8 NAG pH and NNP plot for the desulphurised cover and underlying tailings in July 2000 and August 2011}

The relationship between these two tests can illustrate if a sample is net acid generating, and assist in classification of samples as potentially acid forming, non-acid forming or uncertain (INAP, 2009a). Samples collected in the year $\mathbf{2 0 0 0}$ were classified as either potentially acid forming, with sulphide concentrations of greater than $1 \%$, which consisted of samples taken from the sulphidic tailings below the cover, and samples with sulphide concentrations less than $1 \%$ within the cover. Samples from the 2011 investigation illustrate a decrease in the NAG pH to approximately 2.5 to 6.5 , with positive NNP values. These results indicate that the samples remain non-net-acid forming; however, approximately $20 \%$ of the NAG pH values were less than 4.5 with positive NNP values, which present some uncertainty that the samples will never produce acid. The decrease in NAG pH may be a result of the leaching of alkalinity from the porewater in the tailings profile associated with 10 years of meteoric water infiltration, nevertheless the cover materials continue to indicate sufficient neutralising potential remaining.

End-of-pipe slurry discharge appears to have performed well as a cover to limit oxidation of the underlying sulphidic tailings. Some small areas did show evidence of oxidation at the surface, however, they did not have any significant aerial extent (less than 1-2 $\mathrm{m}^{2}$ ). Trenching was not completed to ascertain the lateral extent, and the oxidised areas may be an artefact of the deposition method or due to insufficient removal of sulphides in the desulphurisation plant. No oxidation front was observed in the 2011 sampling program, and the underlying tailings are finer, and have high saturation. As a result of the high saturation and smaller grain size, the oxygen diffusion coefficient in the sulphidic tailings would be smaller, and minimal oxidation 
in the underlying tailings would be expected. Geochemical analyses indicated a gentle migration toward neutral NAG pH, which was expected as some pyrite was oxidised and consumed within the cover over 11 years. Geochemical data and visual observations support that the cover has not become acidic and has met the design expectations.

\subsubsection{Tailings pond water quality}

The original 244 hectare tailings impoundment was estimated to contain approximately $1.7 \mathrm{Mm}^{3}$ of water and was maintained by a constructed spillway to allow seasonal water release for the post closure period. The spillway location was a key water quality monitoring location during the post-closure period, and 11 years of data has been acquired to document the pond water quality. This water quality is valuable as it indirectly reflects the effectiveness of the tailing cover systems and any effects of oxidation through release of metals or low pH drainage. While a limited spectrum of analyses were conducted for the closure period prior to DGC involvement, a full spectrum of analysis has been performed over the past two years to document the baseline conditions. Trace metals analyses using ICP-MS was completed for the tailings samples, and a review of the major parameters common to both the desulphurised tailings and spillway discharge water are summarised in Table 2 and Table 3 on following page. The geochemistry data for the tailings were assessed against a reference of 10 times crustal natural levels for a typical basalt sample to highlight any anomalous levels. Leading geochemical experts in acid drainage utilise this criteria for prediction and analysis of data to assist in prioritising the key metals of interest. The results presented in Table 2 illustrate that the only metals that had significantly elevated levels were copper, lead and selenium.

A comparison of the trace metals analysis of the desulphurised tailings samples to the water quality data, with respect to total metals, illustrates an absence of leached metals or low $\mathrm{pH}$ drainage to the receiving environment. In general, the most recent tailings pond water quality analyses met the Ontario Provincial Water Quality Objectives (PWQO). This reference was selected as these objectives form the main provincial targets, which are comparable to water quality in a many natural lakes. Mineralised areas have their own unique water quality baselines which often exceed these objectives. Comparison of pond water quality for the elevated metals of interest, including copper, lead and selenium, indicated that all of these metals were close to or below the PWQO. Copper levels were an exception, which were marginally above the PWQO. However, the levels were well below the original discharge permit level of $0.3 \mathrm{mg} / \mathrm{L}$, and also below the recent permit discharge standard of $0.025 \mathrm{mg} / \mathrm{L}$, which is considered very conservative. Cadmium water levels also exceeded the PWQO. The tailing cadmium levels were one tenth of normal crustal abundance, and the source of cadmium on the site is undetermined.

The upper and beach areas of the pond contained substantial vegetation and areas comprised of local aquatic reeds, which were suitable for fish spawning and rearing. The observation of the presence of fish during the 10 year post closure monitoring period supported this conclusion. Northern Pike are present in many of the local lakes and is a primary indicator species. This species is tracked in post closure environmental effects monitoring programs conducted on three-year intervals. The mechanism of colonisation of the pond, though uncertain could be attributed to spillway sluice migration or mid-flight release of fish from predatory birds. However, due to the pond access challenges for fish migration, other indicator species are not present.

In 2010, the tailings impoundment was being prepared for active tailings storage, and the fish were captured for relocation. The relocation employed the use of electro-fishing, purse seines, and gill netting resulting in the removal of 2,284 fish of various species, summarised in Table 4 . The survival rate of the capture and relocation program was $95 \%$. 
Table 2 Summary of tailings sample geochemistry metals scans $(2011)(n=38)$

\begin{tabular}{|c|c|c|c|c|c|c|c|c|c|c|c|c|c|}
\hline $\begin{array}{l}\text { Metal } \\
\text { Units }\end{array}$ & $\begin{array}{c}\text { As } \\
\text { ppm }\end{array}$ & $\begin{array}{l}\mathrm{Ca} \\
\%\end{array}$ & $\begin{array}{c}\mathrm{Cr} \\
\mathrm{ppm}\end{array}$ & $\begin{array}{c}\mathrm{Cd} \\
\mathrm{ppm}\end{array}$ & $\begin{array}{c}\mathrm{Cu} \\
\mathrm{ppm}\end{array}$ & $\begin{array}{l}\mathrm{Fe} \\
\%\end{array}$ & $\begin{array}{l}S \\
\%\end{array}$ & $\begin{array}{l}\mathrm{Mn} \\
\mathrm{ppm}\end{array}$ & $\begin{array}{c}\mathrm{Ni} \\
\mathrm{ppm}\end{array}$ & $\begin{array}{c}\mathrm{Pb} \\
\mathrm{ppm}\end{array}$ & $\begin{array}{c}\mathrm{Zn} \\
\mathrm{ppm}\end{array}$ & $\begin{array}{c}\text { Sb } \\
\text { ppm }\end{array}$ & $\begin{array}{c}\mathrm{Se} \\
\mathrm{ppm}\end{array}$ \\
\hline $\begin{array}{l}\text { Avg. crustal } \\
\text { abundance for } \\
\text { basalt (x10) }\end{array}$ & 20 & - & 1,700 & 2.2 & 870 & - & - & 15,000 & 1,300 & 60 & 1,050 & 2 & 0.5 \\
\hline Maximum & 4.0 & 2.1 & 239.0 & 1.0 & $1,100.0$ & 5.7 & 2.7 & 588.0 & 84.5 & 288.0 & 101.0 & 0.1 & 2.0 \\
\hline Minimum & $<1.0$ & 0.5 & 88.0 & 0.1 & 163.0 & 0.1 & 0.2 & 101.0 & 27.3 & 39.4 & 31.0 & $<0.05$ & $<1.0$ \\
\hline
\end{tabular}

Table 3 Summary of tailings pond water quality at discharge from 2006 to 2010 (T- total metals, D- dissolved metals)

\begin{tabular}{|c|c|c|c|c|c|c|c|c|c|c|c|c|c|c|}
\hline $\begin{array}{l}\text { Metal } \\
\text { Units }\end{array}$ & $\begin{array}{l}\text { As-T } \\
\mathrm{mg} / \mathrm{L}\end{array}$ & $\begin{array}{l}\mathrm{Ca}-\mathrm{T} \\
\mathrm{mg} / \mathrm{L}\end{array}$ & $\begin{array}{l}\mathrm{Cr}-\mathrm{T} \\
\mathrm{mg} / \mathrm{L}\end{array}$ & $\begin{array}{l}\mathrm{Cd}-\mathrm{T} \\
\mathrm{mg} / \mathrm{L}\end{array}$ & $\begin{array}{l}\mathrm{Cu}-\mathrm{T} \\
\mathrm{mg} / \mathrm{L}\end{array}$ & $\begin{array}{l}\text { Fe-T } \\
\mathrm{mg} / \mathrm{L}\end{array}$ & $\begin{array}{c}\mathrm{SO}_{4}-\mathrm{D} \\
\mathrm{mg} / \mathrm{L}\end{array}$ & $\begin{array}{l}\mathrm{Mn}-\mathrm{T} \\
\mathrm{mg} / \mathrm{L}\end{array}$ & $\begin{array}{l}\mathrm{Ni}-\mathrm{T} \\
\mathrm{mg} / \mathrm{L}\end{array}$ & $\begin{array}{l}\mathrm{Pb}-\mathrm{T} \\
\mathrm{mg} / \mathrm{L}\end{array}$ & $\begin{array}{l}\mathrm{Zn}-\mathrm{T} \\
\mathrm{mg} / \mathrm{L}\end{array}$ & $\begin{array}{l}\mathrm{Sb}-\mathrm{T} \\
\mathrm{mg} / \mathrm{L}\end{array}$ & $\begin{array}{l}\mathrm{Se}-\mathrm{T} \\
\mathrm{mg} / \mathrm{L}\end{array}$ & $\begin{array}{c}\text { pH-L } \\
\text { pH units }\end{array}$ \\
\hline PWQO mg/L & 0.1 & N/A & 0.1 & 0.0002 & 0.005 & 0.3 & N/A & N/A & 0.025 & 0.02 & 0.03 & N/A & 0.1 & $6.5-8.5$ \\
\hline Maximum & 0.0080 & 101.0 & 0.0050 & 0.0020 & 0.0169 & 1.090 & 308.0 & 0.2660 & 0.0100 & 0.0199 & 0.0119 & 0.0100 & 0.0200 & 8.65 \\
\hline Minimum & $<0.0002$ & 26.4 & $<0.0004$ & $<0.000003$ & 0.0037 & 0.043 & 55.0 & 0.0016 & $<0.0005$ & 0.0013 & 0.0006 & $<0.0002$ & $<0.001$ & 7.31 \\
\hline
\end{tabular}


Table 4 Fish species captured and released in Detour Gold Mine tailings pond

\begin{tabular}{lccc}
\hline Fish Species & Fish Captured & $\begin{array}{c}\text { Weight of Fish } \\
\text { Captured (kg) }\end{array}$ & $\begin{array}{c}\text { Mortality } \\
\text { (\%) }\end{array}$ \\
\hline Brook stickleback & 98 & 0.2 & 3 \\
Burbot (Age > 1 year) & 581 & 71.9 & 8 \\
Burbot (Age < 1 year) & 996 & 3.4 & 1 \\
Northern Pike & 3 & 1.5 & 0 \\
White Sucker & 606 & 400.3 & 9 \\
Total & 2,284 & 477.3 & 5 \\
\hline
\end{tabular}

Further development of the tailings facility during 2011 required removal of approximately $1.6 \mathrm{Mm}^{3}$ of water. The remaining pond of $120,000 \mathrm{~m}^{3}$ at the end of 2011 froze during the winter months and an additional 299 white suckers and 23 burbot were discovered that perished due to low winter oxygen in the water and a lack of food in the smaller pond. In summary, approximately $88 \%$ of the fish were salvaged and relocated prior to the new tailings facility development.

\section{$5 \quad$ Desulphurised cover advantages and economics}

The Detour Lake Mine tailings cover did not achieve $85 \%$ saturation throughout the cover profile, and matric suction values measured in 2011 indicate the potential for oxygen diffusion. The segregation associated with end-of-pipe discharge methods contribute to the highly heterogeneous grain size profile of the tailings, and small areas of oxidation throughout the cover profile. In future applications of desulphurised tailings cover technology, performance of the cover could be improved with non-segregated tailings, including thickened or paste tailings. Tailings deposited by slurry discharge have high porosity and low mechanical strength, and loose, consolidating materials can pose a risk for long term stability. Nonsegregated tailings have beneficial geotechnical properties such as low saturated hydraulic conductivity and can maintain high saturation (Bussière, 2007).

The Detour Lake Mine site illustrates that mine tailings, which are typically considered a waste product, can be used as a material for remediation and closure as a cover material. Utilising mine waste for a cover eliminates the need to haul additional natural materials to the site to construct an engineered cover. Mitigation of ARD can be achieved through isolation of reactive material from atmospheric oxygen, which is typically addressed through application of a water covers. However, water covers present a permanent geohazard with elevated pore pressures within the tailings and risk of catastrophic failure (Bussière, 2007; INAP, 2009b; Bois et al., 2005). Desulphurisation of the upper zone of the tailings results in an oxygen consuming cover which limits its diffusion into underlying sulphidic tailings and presents a solution with greater geotechnical stability (Bussière, 2007). Success of this cover technology requires that low $\mathrm{pH}$ drainage will not be generated over the long-term, which requires sufficient geochemical analyses to characterise the desulphurised tailings (Bussière, 2007).

Covers costs can range from US\$25,000 to $\$ 100,000$ per hectare, and the design requirements are site specific (INAP, 2009b). A study by Bois et al. (2005) evaluated the cost of different cover technologies with various tailings configurations and considerations required for different types of covers. Figure 9 illustrates desulphurisation cover technology is comparable in cost to underwater disposal or water covers, and are more cost effective than complete desulphurisation or covers with capillary barrier effects (CCBE) (Bois et al., 2005). If the significant additional capital and operating costs of constructing a water containing tailings dam(s) are considered, the use of this type of cover has far lower total costs for all phases from construction through to post closure. 


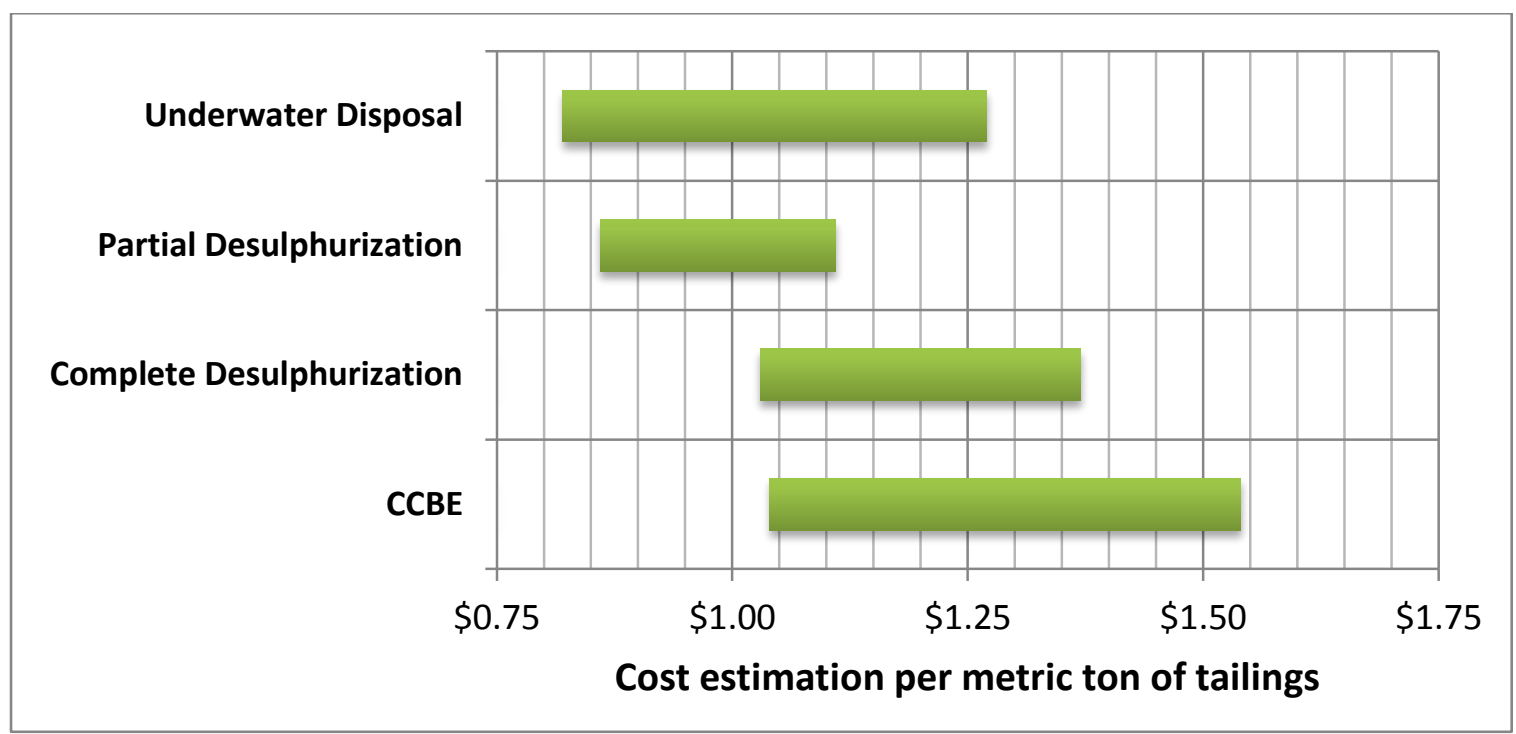

Figure 9 Comparison of costs for capillary barrier covers, complete and partial desulphurisation, and underwater disposal per metric ton of tailings (after Bois et al., 2005)

Complete desulphurisation employed over the entire mine life results in significantly higher implementation costs, and costs increase for tailings with higher AP. Partial desulphurisation is economical as it can be employed in the last stages of the mine life and can be used to cover existing sulphidic tailings. This cover method allows the underlying sulphidic tailings to remain saturated, which limits oxygen diffusion into the tailings, and residual sulphides promote consumption of oxygen (Bois et al., 2005). Partial desulphurisation has similar capital costs to total desulphurisation; however, operational costs are lower as the desulphurisation is only employed at the end of mining operations (Bois et al., 2005). Benzaazoua et al. (2000) evaluated the feasibility of desulphurisation of four different mine tailings waste, and identified that in comparison to haulage costs of natural materials for an engineered cover, desulphurisation is a viable alternative. Desulphurisation is therefore an attractive alternative for reduced site remediation costs, overlooking additional environmental and social requirements at a given site (INAP, 2009b). Water covers or submerged tailings require a climate with an adequate positive water balance (INAP, 2009b), and partial desulphurisation as a cover material can be utilised in sub-humid or semi-arid environments.

\section{Conclusion}

A partially desulphurised tailings cover was installed at the Detour Lake Mine as part of the tailings impoundment closure design. Two investigations were conducted on the cover, first, after installation, and second, 11 years later to assess the long-term performance of the cover design. The objectives of the cover design were to maintain $>85 \%$ saturation to limit oxygen diffusion, and for the residual sulphides to consume oxygen without generating acidic drainage. The initial 2000 site investigation by Sjoberg-Dobchuk et al. (2003) identified through field investigation and numerical analyses that greater than $85 \%$ saturation could not be maintained in the sandy beach region. Some potential for sulphide oxidation existed, however it was concluded that the desulphurised cover system would achieve the objective of preventing acid generation from tailings during the closure period.

The opportunity to conduct additional sampling 11 years later provided geochemical confirmation that the cover is non-net-acid generating, and it is evident that even without high saturation in the desulphurised tailings, performance of the cover has met the design expectations. Visual observations and sampling during the follow-up field investigation in 2011 did not show an oxidation front in the tailings profile, and only small thin isolated stringers of oxidation in a few holes. The NAG pH showed a migration toward neutral $\mathrm{pH}$ as pyrite has been consumed reducing the overall NP. Tailings pond water quality did not show significant impacts due to tailings oxidation and data met or exceeded the Ontario PWQO for most metals. 
Copper levels were close to the PWQO levels and were well below the past and current permit standards. Cadmium mean water levels exceeded the PWQO of $0.0002 \mathrm{mg} / \mathrm{l}$ but the source could not be explained. The tailings pond had excellent water quality and fish populations which appear to be viable despite hydrologic isolation from local lakes. This indirectly supports that the cover system is performing well with no evidence of significant metal leaching to the receiving environment. The existing tailings will be flooded by an additional $100 \mathrm{M}$ tonnes of new tailings, which will have low sulphide content and are predicted to be non-acid generating.

A partially desulphurised cover is an advantageous option for closure, as it serves as an oxygen consuming and diffusion barrier. Therefore this study confirms one of the key assumptions that formed the basis of the closure plan and approved closure permit, that a water cover is not required at this particular site. This cover technology is advantageous from a geotechnical perspective as pore pressures in the tailings are lower, and tailings can be used as a material for closure as a cover material. In comparison to other common cover methodologies, a partially desulphurised cover is comparable in cost to a water cover, without the additional geotechnical risks associated with high pore pressures including potential for piping, liquefaction, and overtopping (Bois et al., 2005; Bussière, 2007). Capital costs for tailings technologies such as environmental desulphurisation can be high; however, it can reduce the environmental risks (Bussière, 2007). Consequently, concern by a range of stakeholders including NGOs, communities and government agencies for the long term post-closure time frame have promoted a shift towards alternate waste solutions that do not rely on water covers and water retaining dams. Evaluation of alternative tailings technologies such as environmental desulphurisation is a valid method to consider for tailing closure management, as higher costs can be offset by reduction of environmental risks (Bussière, 2007).

\section{Acknowledgement}

The authors would like to acknowledge the Environmental Department staff at Detour Gold Corporation for their assistance in collection of data and support for this project. The authors also acknowledge Bonnie Sjoberg-Dobchuk for the on the initial investigation, which made this project possible.

\section{References}

AMEC Earth \& Environmental (08/2010) Detour Lake Project: Environmental Study Report MNR Class EA, Mississauga, pp. 5-117.

Benzaazoua, M., Bussiere, B., Kongolo, M., McLaughlin, J. and Marion, P. (2000) Environmental desulphurisation of four Canadian mine tailings using froth flotation, International Journal of Mineral Processing, Vol. 60, pp. 57-74.

Bois, D., Benzaazoua, M., Bussiere, B., Kongolo, M. and Poirier, P. (2005) A feasibility study on the use of desulphurised tailings to control acid mine drainage, CIM Bulletin, Vol, 98(1087), pp. 74.

Bussiere, B., Benzaazoua, M., Aubertin, M. and Mbonimpa, M. (2004) A laboratory study of covers made of low-sulphide tailings to prevent acid mine drainage, Environmental Geology, Vol. 45, pp. 609-622.

Bussière, B. (2007) Colloquium 2004: Hydrogeotechnical properties of hard rock tailings from metal mines and emerging geoenvironmental disposal approaches, Canadian Geotechnical Journal, Vol. 44, pp. 1019-1052.

International Network for Acid Prevention (INAP) (2009a) International Network for Acid Prevention, Ottawa, viewed 30 May 2012, http://www.gardguide.com/index.php/Chapter_5.

International Network for Acid Prevention (INAP) (2009b) International Network for Acid Prevention, Ottawa, viewed 30 May 2012 , http://www.gardguide.com/index.php/Chapter_6.

Mine Environment Neutral Drainage (MEND) (02/1999) Construction and instrumentation of a multi-layer cover: Les terrains aurifères, MEND Report 2.22.4a, CANMET, viewed 8 May 2012, http://www.mendnedem.org/reports/files/2.22.4a\%20E.pdf.

Mine Environment Neutral Drainage (MEND) (03/2001) MEND Manual Volume 1 - Summary, Report 5.4.2a, Tremblay, G.A. and Hogan, C.M. (eds) Mine Environment Neutral Drainage (MEND), CANMET, viewed 1 May 2012, http://www.mendnedem.org/reports/files/5.4.2a.pdf.

Sjoberg-Dobchuk, B., Wilson, G.W. and Aubertin, M. (2003) Evaluation of a single-layer desulfurised tailings cover, in Proceedings 6th International Conference on Acid Rock Drainage, 12-18 July, Cairns, Australia, pp. 373-381. 